\title{
Resveratrol: a supplementation for men or for mice?
}

Valentina Ponzo ${ }^{1}$, Laura Soldati2 ${ }^{2^{*}}$ and Simona Bo ${ }^{1}$

\begin{abstract}
Resveratrol is a polyphenolic compound found in several plants. In the last decades, the interest in this compound has enormously increased after benefits on metabolism and increased lifespan of various organisms have been reported with its supplementation. Several in-vitro and animal studies have observed that resveratrol can act on multiple molecular targets, including sirtuins, a class of NAD + -dependent deacetylases. Despite the enthusiastic results reported in many animal- and in-vitro studies, few trials have been performed in humans with contrasting results. These conflicting data may be due at least in part to differences in the characteristics of the patients enrolled, the dosages and the duration of supplementation. Furthermore, many questions remain still unsolved, such as the dose or the duration of treatment to maximize its effects, the bioavailability of resveratrol and the role of food matrix to improve its bioactivity. In conclusion, at present the use of resveratrol as a supplement is not yet justified by the existing evidence.
\end{abstract}

Keywords: Polyphenoles, Resveratrol, Wine

\section{Background}

The phytoalexin resveratrol (3,5,4'-trihydroxystilbene), a non-flavonoids polyphenolic compound found in many plants such as grapes, and in red wine was first discovered in 1940 [1,2].

Resveratrol owes its fame to the so-called "French Paradox". In the early 90s, the term derived from the observation that the French adults showed a relatively low incidence of coronary heart disease in comparison to the corresponding-age individuals from other Western countries, despite a high dietary intake of saturated fatty acids. The French scientist Renaud attributed this paradox to the increased consumption of red wine [3] and, later, the high resveratrol content of wine has been identified as one of the potential mechanisms of the benefits of red wine [4]. From that moment, the interest in this natural compound has grown enormously. Research has thereafter shifted from human to animal models and the number of studies on resveratrol has increased extraordinarily since 1997, when its anti-cancer properties have been reported [4]. Several authors have investigated the hypothetical cardioprotective, anti-cancer, anti-

\footnotetext{
* Correspondence: laura.soldati@unimi.it

${ }^{2}$ Department of Health Sciences, University of Milan, Milan, Italy

Full list of author information is available at the end of the article
}

inflammatory and antioxidant properties of resveratrol. A long list of beneficial effects and many possible direct or indirect molecular targets and mechanisms of action of resveratrol have been described in animal and in vitro studies. Only recently, research has focused on humans again, and so far a number of human clinical trial have been conducted.

\section{Main text}

A milestone in resveratrol research came in the early 2000s when some authors reported that resveratrol is able to mimic caloric restriction effects and increased yeast, worms, flies and rodents lifespan [5,6]. This effect was ascribed to the resveratrol ability to activate sirtuin proteins, $\mathrm{NAD}^{+}$-dependent de-acetylase involved in the regulation of metabolism, apoptosis, mitochondrial biogenesis, inflammation, fatty acid metabolism, and glucose homeostasis [7-10]. But sirtuins are not the only target of resveratrol and thanks to its ability to act on numerous molecular targets, resveratrol exhibits versatile biological effects: from the inhibition of angiogenesis, cancer cell and metastatic cell growth [11-24] to the improvement of vascular function, arterial blood pressure values, and platelet aggregation [25-27], and the anti-inflammatory [28,29], antioxidant [30,31] and hypoglycaemic effects [32-38]. 
To date, the human clinical trials available have shown conflicting or controversial results about the anticancer, cardioprotective and anti-inflammatory properties of resveratrol [39-50]. Other sources of controversy derive from the fact that many of the hypothesized mechanisms have not yet been demonstrated in humans [27]. However, some positive results have been found. A recent meta-analysis of 11 human clinical trials, investigating the effects of resveratrol on the metabolic pattern of type 2 diabetic patients, points out a beneficial effect of resveratrol consumption on fasting glucose and glycosylated haemoglobin values, and insulin resistance measured by the homeostatic model assessment [51].

Why have not all the promising results found in preclinical studies been confirmed in humans?

Differences in formulation, dosage of resveratrol and duration of follow-up may at least in part justify these conflicting results. However, many other issues remain unresolved. For example, the dose of resveratrol to maximize its effects without safety concerns is still unknown; similarly the duration of supplementation remains a matter of concern (a high dose for a short-term or a low dose for a long period?). Moreover, the relationship between the low bioavailability and the high bioactivity of resveratrol, the so-called resveratrol paradox, has not yet been solved. Since this molecule is rapidly metabolized and its concentrations quickly disappear in the blood, it is difficult to justify its benefits, while the knowledge of metabolites or mediators responsible for the effects of resveratrol is still scanty [52].

The majority of trans-resveratrol metabolites were found to be derived by glucuronidation or sulfation. Since the rapid metabolism seems to be one of the major reasons for the lower effect on humans, a part of the research is focusing on how to improve the bioavailability of resveratrol. One way to improve the bioavailability may be the combination of resveratrol with other agents that inhibit its metabolism in vivo. Studies have shown that natural compounds, including quercetin and piperine (an alkaloid derived from black pepper), can inhibit glucuronidation and sulfation of resveratrol [53-55]. However, further studies are needed to assess whether these combinations may determine an increase in its bioavailability.

The role of resveratrol in an "epigenetic diet", a diet with a potential impact in delaying ageing and preventing age-related diseases, could be a further topic worthy of investigation.

Finally, another interesting but unsolved topic is the possible influence of the food matrix on the bioavailability of resveratrol in humans. Some authors have shown that trans-resveratrol is better absorbed when assumed through wine or grape juice than from tablets [56]; in vivo bioavailability and bioactivity could be increased by the food matrix because of the presence of other natural compounds, such as other polyphenols that seem to play a synergic role and increase resveratrol bioactivity [57].

\section{Conclusions}

The versatile properties of resveratrol found in in-vitro and animal studies have not been unequivocally confirmed in human studies. At present, resveratrol should be assumed by natural foods, mainly through the moderate consumption of red wine, grape juice or peanuts, while the consumption as a supplement is not justify by the existing scientific literature. Many issues remain certainly open, and a resveratrol formulation with increased bioavailability and effective in humans as in mice has yet to be discovered.

\section{Competing interests}

The authors declare that they have no competing interests.

\section{Authors' contributions}

VP participated in the conception of the manuscript, literature collection and interpretation, manuscript writing and revision. LS participated in the conception of the manuscript, literature interpretation, manuscript writing and revision. SB participated in the conception of the manuscript, literature interpretation, manuscript writing and revision. All authors have read and approved the final manuscript.

\section{Author details}

'Department of Medical Sciences, University of Turin, Turin, Italy.

${ }^{2}$ Department of Health Sciences, University of Milan, Milan, Italy.

Received: 20 May 2014 Accepted: 20 May 2014

Published: 3 June 2014

\section{References}

1. Scalbert A, Williamson G: Dietary intake and bioavailability of polyphenols. J Nutr 2000, 130:2073S-2085S.

2. Burns J, Yakota T, Ashihara H, Lean MEJ, Crozier A: Plant foods and herbal sources of resveratrol. J Agric Food Chem 2002, 50:3337-3340.

3. Renaud S, de Lorgeril M: Wine, alcohol, platelets, and the French paradox for coronary heart disease. Lancet 1992, 339:1523-1526.

4. Jang M, Cai L, Udeani GO, Slowing KV, Thomas CF, Beecher CW, Fong HH, Farnsworth NR, Kinghorn AD, Mehta RG, Moon RC, Pezzuto JM: Cancer chemopreventive activity of resveratrol, a natural product derived from grapes. Science 1997, 275:218-220.

5. Baur JA, Pearson KJ, Price NL: Resveratrol improves health and survival of mice on a high-calorie diet. Nature 2006, 444:337-342.

6. Howitz KT, Bitterman KJ, Cohen HT: Small molecule activators of sirtuins extend Saccharomyces cerevisiae lifespan. Nature 2003, 425:191-196.

7. Lagouge M, Argmann C, Gehart-Hines Z: Resveratrol improves mitochondrial function and protects against metabolic disease by activating SIRT1 and PRG-1. Cell 2006, 127:1-14.

8. Csiszar A, Labinskyy N, Pinto JT, Ballabh P, Zhang HR, Losonczy G, Pearson K, de Cabo R, Pacher P, Zhang $C H$, Ungvari Z: Resveratrol induces mitochondrial biogenesis in endothelial cells. Am J Physiol Heart Circ Physiol 2009, 297:H13-H2O.

9. Kao CL, Chen LK, Chang YL, Yung MC, Hsu CC, Chen YC, Lo WL, Chen SJ, $\mathrm{Ku} \mathrm{HH}$, Hwang SJ: Resveratrol protects human endothelium from $\mathrm{H}$ 2O2-induced oxidative stress and senescence via Sirt1 activation. J Atheroscler Thromb 2010, 17:970-979.

10. Wang GL, Fu YC, Xu WC, Feng YQ, Fang SR, Zhou XH: Resveratrol inhibits the expression of SREBP1 in cell model of steatosis via Sirt1-FOXO1 signaling pathway. Biochem Biophys Res Commun 2009, 380:644-649.

11. Shankar S, Singh G, Srivastava RK: Chemoprevention by resveratrol: molecular mechanisms and therapeutic potential. Front Biosci 2007, 12:4839-4854 
12. Aziz MH, Kumar R, Ahmad N: Cancer chemoprevention by resveratrol: in vitro and in vivo studies and the underlying mechanisms. Int J Oncol 2003, 23:17-28.

13. Aziz MH, Nihal M, Fu VX, Jarrard DF, Ahmad N: Resveratrol-caused apoptosis of human prostate carcinoma LNCaP cells is mediated via modulation of phosphatidylinositol 3_-kinase/Akt pathway and $\mathrm{BCl}-2$ family proteins. Mol Cancer Ther 2006, 5:1335-1341.

14. Reagan-Shaw S, Afaq F, Aziz MH, Ahmad N: Modulations of critical cell cycle regulatory events during chemoprevention of ultraviolet $B$ mediated responses by resveratrol in SKH-1 hairless mouse skin. Oncogene 2004, 23:5151-5160.

15. Lee HS, Ha AW, Kim WK: Effect of resveratrol on the metastasis of 4 T1 mouse breast cancer cells in vitro and in vivo. Nutr Res Pract 2012, 6:294-300.

16. Atten MJ, Godoy-Romero E, Attar BM, Milson T, Zopel M, Holian O: Resveratrol regulates cellular PKC alpha and delta to inhibit growth and induce apoptosis in gastric cancer cells. Invest New Drugs 2005, 23:111-119.

17. Huderson AC, Myers JN, Niaz MS, Washington MK, Ramesh A: Chemoprevention of benzo(a)pyrene-induced colon polyps in Apc(Min) mice by resveratrol. J Nutr Biochem 2012, 24:713-724.

18. Juan ME, Alfaras I, Planas JM: Colorectal cancer chemoprevention by trans-resveratrol. Pharmacol Res 2012, 65:584-591.

19. Patel KR, Brown VA, Jones DJ, Britton RG, Hemingway D, Miller AS, West KP, Booth TD, Perloff M, Crowell JA, Brenner DE, Steward WP, Gescher AJ, Brown K: Clinical pharmacology of resveratrol and its metabolites in colorectal cancer patients. Cancer Res 2010, 70:7392-7399.

20. Athar M, Back JH, Tang X, Kim KH, Kopelovich L, Bickers DR, Kim AL: Resveratrol: a review of preclinical studies for human cancer prevention. Toxicol Appl Pharmacol 2007, 224:274-283.

21. Malhotra A, Nair P, Dhawan DK: Curcumin and resveratrol synergistically stimulate p21 and regulate cox-2 by maintaining adequate zinc levels during lung carcinogenesis. Eur J Cancer Prev 2011, 20:411-416.

22. Howells LM, Berry DP, Elliott PJ, Jacobson EW, Hoffmann E, Hegarty B, Brown K, Steward WP, Gescher AJ: Phase I randomized, doubleblind pilot study of micronized resveratrol (SRT501) in patients with hepatic metastases-safety, pharmacokinetics, and pharmacodynamics. Cancer Prev Res 2011, 4:1419-1425.

23. Vang O, Ahmad N, Baile CA, Baur JA, Brown K, Csiszar A, Das DK, Delmas D, Gottfried C, Lin HY, Ma QY, Mukhopadhyay P, Nalini N, Pezzuto JM, Richard T, Shukla Y, Surh YJ, Szekeres T, Szkudelski T, Walle T, Wu JM: What is new for an old molecule? Systematic review and recommendations on the use of resveratrol. PLOS One 2011, 6:e19881.

24. Salado C, Olaso E, Gallot N, Valcarcel M, Egilegor E, Mendoza L, VidalVanaclocha F: Resveratrol prevents inflammation-dependent hepatic melanoma metastasis by inhibiting the secretion and effects of interleukin-18. J Transl Med 2011, 9:59.

25. Wu JM, Hsieh TC: Resveratrol: a cardioprotective substance. Ann N Y Acad Sci 2011, 1215:16-21.

26. Wang H, Yang YJ, Qian HY, Zhang Q, Xu H, Li JJ: Resveratrol in cardiovascular disease: what is known from current research? Heart Fail Rev 2012, 17:437-448.

27. Tomé-Carneiro J, Larrosa M, González-Sarrías A, Tomás-Barberán FA, García-Conesa MT, Espín JC: Resveratrol and clinical trials: the crossroad fromin vitro studies to human evidence. Curr Pharm Des 2013, 19:6064-6093

28. Manna SK, Mukhopadhyay A, Aggarwal BB: Resveratrol suppresses TNFinduced activation of nuclear transcription factors NF-B, activator protein-1, and apoptosis: potential role of reactive oxygen intermediates and lipid peroxidation. J Immunol 2000, 164:6509-6519.

29. Holmes MM, Baldwin ASJ: Chemopreventive properties of trans-resveratrol are associated with inhibition of activation of the IB kinase. Cancer Res 2000, 60:3477-3483.

30. Rocha KKR, Souza GA, Ebaid GX, Seiva FRF, Cataneo AC, Novelli ELB: Resveratrol toxicity: effects on risk factors for atherosclerosis and hepatic oxidative stress in standard and high-fat diets. Food Chem Toxicol 2009, 47:1362-1367

31. Li Y, Cao Z, Zhu H: Upregulation of endogenous antioxidants and phase 2 enzymes by the red wine polyphenol, resveratrol in cultured aortic smooth muscle cells leads to cytoprotection against oxidative and electrophilic stress. Pharmacol Res 2006, 53:6-15.
32. Su HC, Hung LM, Chen JK: Resveratrol, a red wine antioxidant, possesses an insulin-like effect in streptozotocin-induced diabetic rats. Am J Physio/ Endocrinol Metab 2006, 290:E1339-1346.

33. Palsamy $P$, Subramanian S: Ameliorative potential of resveratrol on proinflammatory cytokines, hyperglycemia mediated oxidative stress, and pancreatic beta-cell dysfunction in streptozotocin-nicotinamideinduced diabetic rats. J Cell Physiol 2010, 224:423-432.

34. Palsamy P, Subramanian S: Resveratrol, a natural phytoalexin, normalizes hyperglycemia in streptozotocin-nicotinamide induced experimental diabetic rats. Biomed Pharmacother 2008, 62:598-605.

35. Timmers S, Konings E, Bilet L, Houtkooper RH, van de Weijer T, Goossens $\mathrm{GH}$, Hoeks J, van der Krieken S, Ryu D, Kersten S: Calorie restriction-like effects of 30 days of resveratrol supplementation on energy metabolism and metabolic profile in obese humans. Cell Metab 2011, 14:612-622

36. Lagouge M, Argmann C, Gerhart-Hines Z, Meziane H, Lerin C, Daussin F, Messadeq N, Milne J, Lambert P, Elliott P: Resveratrol improves mitochondrial function and protects against metabolic disease by activating SIRT1 and PGC-1alpha. Cell 2006, 127:1109-1122.

37. Penumathsa SV, Thirunavukkarasu M, Zhan L, Maulik G, Menon VP, Bagchi D, Maulik N: Resveratrol enhances GLUT-4 translocation to the caveolar lipid raft fractions through AMPK/Akt/eNOS signaling pathway in diabetic myocardium. J Cell Mol Med 2008, 12:2350-2361

38. Chi TC, Chen WP, Chi TL, Kuo TF, Lee SS, Cheng JT, Su M. Phosphatidylinositol-3-kinase is involved in the antihyperglycemic effect induced by resveratrol in streptozotocin-induced diabetic rats. Life SCi 2007, 80:1713-1720

39. Tomé-Carneiro J, Gonzálvez M, Larrosa M, Yáñez-Gascón MJ, García-Almagro FJ, Ruiz-Ros JA, Tomás-Barberán FA, García-Conesa MT, Espín JC: Resveratrol in primary and secondary prevention of cardiovascular disease: a dietary and clinical perspective. Ann N Y Acad Sci 2013, 1290:37-51.

40. Sahebcar A: Effects of resveratrol supplementation on plasma lipids: a systematic review and meta-analysis of randomized controlled trials. Nutr Rev 2013, 71:822-835.

41. Ghanim H, Sia CL, Abuaysheh S, Korzeniewski K, Patnaik P, Marumganti A, Chaudhuri A, Dandona P: An antiinflammatory and reactive oxygen species suppressive effects of an extract of Polygonum cuspidatum containing resveratrol. J Clin Endocrinol Metab 2010, 95:E1-E8.

42. Bo S, Ciccone G, Castiglione A, Gambino R, De Michieli F, Villois P, Durazzo M, Cavallo-Perin P, Cassader M: Antiinflammatory and Antioxidant Effects of Resveratrol in Healthy Smokers. Curr Med Chem 2012, 20:1323-1331.

43. Poulsen MM, Vestergaard PF, Clasen BF, Radko Y, Christensen LP, StødkildeJørgensen H, Møller N, Jessen N, Pedersen SB, Jørgensen JO: High-Dose Resveratrol Supplementation in Obese Men: An Investigator-Initiated, Randomized, Placebo-Controlled Clinical Trial of Substrate Metabolism, Insulin Sensitivity, and Body Composition. Diabetes 2012, 62:1186-1195.

44. Yoshino J, Conte C, Fontana L, Mittendorfer B, Imai S, Schechtman KB, Gu C, Kunz I, Rossi Fanelli F, Patterson BW, Klein S: Resveratrol supplementation does not improve metabolic function in nonobese women with normal glucose tolerance. Cell Metab 2012, 16:658-664.

45. Crandall JP, Oram V, Trandafirescu G, Reid M, Kishore P, Hawkins M, Cohen HW, Barzilai N: Pilot Study of resveratrol in Older Adults With Impaired Glucose Tolerance. J Gerontol A Biol Sci Med Sci 2012, 67:1307-1312.

46. Fujitaka K, Otani H, Jo F, Jo H, Nomura E, Iwasaki M, Nishikawa M, Iwasaka T, Das DK: Modified resveratrol Longevinex improves endothelial function in adults with metabolic syndrome receiving standard treatment. Nutr Res 2011, 31:842-847.

47. Tomé-Carneiro J, Gonzálvez M, Larrosa M, Yáñez-Gascón MJ, Garcìa-Almagro FJ, Ruiz-Ros JA, Garcì-Conesa MT, Tomàs-Barbéran FA, Espìn JC: One-year consumption of a grape nutraceutical containing resveratrol improves the inflammatory and fibrinolytic status of patients in primary prevention of cardiovascular disease. Am J Cardiol 2012, 110:356-363.

48. Magyar K, Halmosi R, Palfi A, Feher G, Czopf L, Fulop A, Battyany I, Sumegi B, Toth K, Szabados E: Cardioprotection by resveratrol: A human clinical trial in patients with stable coronary artery disease. Clin Hemorheol Microcirc 2012, 50:179-187.

49. Heger A, Ferk F, Nersesyan A, Szekeres T, Kundi M, Wagner KH, Haidinger G, Misik $M$, Knasmuller $S$ : Intake of a resveratrol- containing dietary supplement has no impact on DNA stability in healthy subjects. Mutat Res 2012, 749:82-86.

50. Militaru C, Donoiu I, Craciun A, Scorei ID, Bulearca AM, Scorei Rl: Oral resveratrol and calcium fructoborate supplementation in subjects with 
stable angina pectoris: Effects on lipid profiles, inflammation markers, and quality of life. Nutrition 2013, 29:178-183.

51. Liu K, Zhou R, Wang B, Mi MT: Effect of resveratrol on glucose control and insulin sensitivity: a meta-analysis of 11 randomized controlled trials. Am J Clin Nutr. in press.

52. Walle T: Bioavailability of resveratrol. Ann N Y Acad Sci 2011, 1215:9-15.

53. de Santi C, Pietrabissa A, Mosca F, Pacifici GM: Glucuronidation of resveratrol, a natural product present in grape and wine, in the human liver. Xenobiotica 2000, 30:1047-1054.

54. De Santi C, Pietrabissa A, Spisni R, Mosca F, Pacifici GM: Sulphation of resveratrol, a natural product present in grapes and wine, in the human liver and duodenum. Xenobiotica 2000, 30:609-617.

55. Johnson JJ, Nihal M, Siddiqui IA, Scarlett CO, Bailey HH, Mukhtar H, Ahmad N: Enhancing the bioavailability of resveratrol by combining it with piperine. Mol Nutr Food Res 2011, 55:1169-1176.

56. Ortuño J, Covas MI, Farre M, Pujadas M, Fito M, Khymenets O, Andres- Lacueva C, Roset P, Joglar J, Lamuela-Raventos RM, de la Torre R: Matrix effects on the bioavailability of resveratrol in humans. Food Chem 2010, 4:1123-1130.

57. Scheepens A, Tan K, Paxton JW: Improving the oral bioavailability of beneficial polyphenols through designed synergies. Genes Nutr 2010, 5:75-87.

doi:10.1186/1479-5876-12-158

Cite this article as: Ponzo et al:: Resveratrol: a supplementation for men or for mice?. Journal of Translational Medicine 2014 12:158.

\section{Submit your next manuscript to BioMed Central and take full advantage of:}

- Convenient online submission

- Thorough peer review

- No space constraints or color figure charges

- Immediate publication on acceptance

- Inclusion in PubMed, CAS, Scopus and Google Scholar

- Research which is freely available for redistribution 